International Journal of Food Microbiology

November 2015, Volume 213, Pages 79-87

http://dx.doi.org/10.1016/j.ijfoodmicro.2015.05.005

http://archimer.ifremer.fr/doc/00268/37966/

(c) 2015 Elsevier B.V. All rights reserved.

\title{
Selection of bioprotective cultures for preventing cold-smoked salmon spoilage
}

\author{
Leroi Francoise ${ }^{1,{ }^{*}}$, Cornet Josiane ${ }^{2}$, Chevalier Frédérique ${ }^{1}$, Cardinal Mireille ${ }^{2}$, Coeuret Gwendoline ${ }^{3,}$ \\ ${ }^{4}$, Chaillou Stéphane ${ }^{3,4}$, Joffraud Jean-Jacques ${ }^{1}$
}

${ }^{1}$ Ifremer, Laboratoire Ecosystèmes Microbiens et Molécules Marines pour les Biotechnologies (EM3B), BP 21105, 44311 Nantes, France

${ }_{2}$ Ifremer, Laboratoire Bioressources Marines et Bioraffinerie par hydrolyse enzymatique (BIORAF HE),

BP 21105, 44311 Nantes, France

${ }^{3}$ INRA, UMR1319 Micalis, Lactic Acid Bacteria \& Meat Microbial Ecosystems Laboratory, Domaine de

Vilvert, Bâtiment 526, F-78350 Jouy-en-Josas, France

${ }^{4}$ AgroParisTech, INRA Micalis, Paris, France

*Corresponding author : Françoise Leroi, email address : francoise.leroi@ifremer.fr

josiane.cornet@ifremer.fr ; fchevali@ifremer.fr ; mireille.cardinal@ifremer.fr ; gwendoline.coeuret@jouy.inra.fr ; stephane.chaillou@jouy.inra.fr ; jean.jacques.joffraud@ifremer.fr

\begin{abstract}
:
Biopreservation is a natural technology of food preservation, which consists of inoculating food with microorganisms selected for their antibacterial properties. The objective of this study was to select lactic acid bacteria (LAB) to improve the quality of cold-smoked salmon (CSS). In this work, different strains representative of the 4 dominant species, identified in a previous study by pyrosequencing the $16 \mathrm{~S}$ rRNA gene, were isolated and their spoiling potential in CSS blocks, sterilized by ionization, was assessed by twelve trained panelists along the vacuum storage at $8^{\circ} \mathrm{C}$. Photobacterium phosphoreum, Brochothrix thermosphacta and Serratia proteamaculans released strong off-odors whereas the spoiling potential of Carnobacterium divergens was weaker. The spoiling capacity of Lactococcus piscium EU2241, Leuconostoc gelidum EU2247, Lactobacillus sakei EU2885, Staphylococcus equorum S030674 and 4 commercial starters was tested by the same method and 2 strains were eliminated due to off-odor production. The effect of the 6 selected LAB against the 4 specific spoiling organisms (SSOs) selected was tested by challenge tests in sterile CSS blocks. The protective effect of the LAB differed from one SSO to another and no correlation could be established between the sensory improvement, SSO inhibition, and the implantation or acidification of protective cultures (PCs). All the PCs except $L$. piscium reduced the off-odors released by $P$. phosphoreum although some of them had no effect on its growth. S. equorum, which did not grow in CSS, favored the implantation of $P$. phosphoreum but prevented its off-odor formation. $L$. piscium was the only strain that prevented the spoilage of $B$. thermosphacta and $S$. proteamaculans although it did not grow very well and did not acidify the product. L. gelidum EU2247 inhibited the growth of these 2 SSOs and lowered the $\mathrm{pH}$ but had no effect on the sensory quality. Finally, L. piscium was tested in 2 naturally contaminated products, with a positive effect on 1 batch. This effect was not correlated with the microbial ecosystem as determined by acultural and cultural techniques. Based on these results, the selection strategy is discussed.
\end{abstract}




\section{Highlights}

- Four specific spoilage bacteria of cold-smoked salmon were identified - Eight protective cultures were tested in situ against the four spoilage bacteria Lactococcus piscium EU2241 improved the sensory quality of cold-smoked salmon - There was no correlation between sensory improvement and microbial ecosystem

Keywords: biopreservation, lactic acid bacteria, sensory analysis, seafood products, microbial ecosystem, pyrosequencing 


\section{Introduction}

In response to the increased demand for tasty and healthy food, as well as the appearance of new eating habits and culinary trends, a variety of seafood has been developed such as products eaten raw (sushi, carpaccio, tartar), lightly preserved (smoked, pickled, salted) or ready-to-eat (peeled cooked crustaceans, fish sausage) and convenience foods (fish or shellfish packed under vacuum or modified atmosphere). These products are highly perishable since pathogenic or spoiling bacteria, naturally present in the marine environment or due to recontamination, can develop. It is estimated that over $20 \%$ of seafood loss is related to microbial degradation (FAO, 2011) and that 10 to $70 \%$ of food outbreaks are linked to the consumption of seafood (Doré, 2008). The quality and microbiological safety of food is based on the application of different treatments to eliminate microorganisms or prevent their development during storage. Conventional decontamination treatments cause unacceptable sensory degradation for these delicate products. Modern mildtechnologies (such as pulsed light or high pressure) are often ineffective while chemical preservatives are poorly perceived by consumers. Biopreservation, also named bioconservation, is a method of preserving food using microorganisms, which are thus called protective cultures (PCs) (Zagorec and Christeans, 2013). This technology consists of inoculating a food with a non-pathogenic microorganism, selected to prevent the development of other undesirable microbes (Pilet and Leroi, 2011). It can be compared to the biological control used in agronomy to eliminate harmful insects or animals by their natural predators. The use of bacteria in unfermented products in which no sensory and nutritional modification is required dates back only twenty years (Leroi, 2010). LAB are good candidates for biopreservation because (i) they have many natural antibacterial properties (ii) they are part of the common flora of many foods; (iii) they are recognized as non-hazardous to human health; (iv) they benefit from a healthy image conveyed to consumers by dairy products (Ghanbari et 
al, 2013). The strategy for selecting PCs consists of a nine-step process summarized in Figure 1. First, the undesirable target microorganisms must be identified. This is easy for pathogenic bacteria but more complicated for spoilage, which is caused by different and often unknown microorganisms. A collection of presumptive PCs must then be set up. The first screening is based on the inhibition of the target strains by strains from the PC collection in model conditions. Different techniques are available such as tests in laboratory broth or diffusion tests on agar plates containing the target bacteria and spots, discs or wells of the presumptive PCs (Matamoros et al., 2009a; Odeyemi et al., 2011). The culture medium must be carefully chosen as it can influence the results. Some taxonomic and physiological data are required (e.g. acid production, growth at low temperature), as well as information about safety aspects (resistance to antibiotics, production of toxic molecules, invasiveness) and technological properties (PC production yield, resistance to lyophilization). The absence of spoilage potential by PCs must be tested in sterile food. The inhibitory effect of the candidates is then tested against the target microorganisms by co-inoculation in the sterile food matrix. Finally, the selected PCs are tested in naturally contaminated products at laboratory scale and can then be tested and implemented in industry.

CSS is a mildly processed product in which Listeria monocytogenes is one of the major human pathogens (Jami et al., 2014). Different authors have selected PCs with a listericidal or listeriostatic effect and successfully tested them in the product (Brillet et al., 2004, 2005; Katla et al., 2001; Tahiri et al., 2009). On the other hand, its short sensory shelf-life (3-6 weeks) due to microbial development is a limiting factor for the commercialization and export of CSS (Cardinal et al., 2004; Leroi et al., 2001). To our knowledge, biopreservation has never been developed to extend the shelf-life and improve the quality of this product, except an attempt by Leroi et al (1996). The objective of this study was thus to select one PC, based on the strategy presented in Figure 1, and test its effect on the sensory characteristics and microbial ecosystem dynamics of naturally contaminated products. Based on the results, the selection strategy is discussed. 


\section{Materials and methods}

\subsection{Isolation of bacterial strains from spoiled cold-smoked salmon}

Bacteria were isolated from 10 batches of spoiled CSS studied in a previous project (Chaillou et al., 2014). Thirty grams of flesh was homogenized for $2 \times 2$ min (Stomacher@ 400 circulator Seward, Worthing, England) with $120 \mathrm{~mL}$ tryptone salt water (tryptone $1 \mathrm{~g} / \mathrm{L}, \mathrm{NaCl} 8.5 \mathrm{~g} / \mathrm{L}$ ) and $1 \%$ Tween 80 . One hundred microliters of successive dilutions of the mother solution was spread onto plates of modified Long and Hammer's medium (LH) (Van Spreekens, 1974) incubated at $15^{\circ} \mathrm{C}$ for 5 days, Streptomycin Thallium Acetate Agar (STAA, Oxoid, Basingstoke, Hampshire, England) at $20^{\circ} \mathrm{C}$, Elliker agar (Biokar Diagnostics, Beauvais, France) at $20^{\circ} \mathrm{C}$ in anaerobic conditions (Anaerocult A, Merck, Darmstadt, Germany) and pour plates of Tryptone Soy Agar (TSA, Biokar Diagnostics) overlaid by Violet Red Bile Glucose agar (VRBG, Biokar Diagnostic) at $30^{\circ} \mathrm{C}$ for 2 days. Different colonies from plates containing 30-100 colonies were purified twice successively on Brain Heart Infusion agar plates (BHI, Biokar Diagnostics) and identified by partial sequencing of the 16S rRNA gene (approx. $700 \mathrm{bp}$ ).

\subsection{Bacterial strains and pre-culturing}

The bacterial strains used in this study are listed in Table 1. Potential protective LAB were selected from commercial starters and collections from Ifremer/Oniris (Nantes, France) and INRA (Theix, France). They were cultivated in Elliker or de Man, Rogosa and Sharpe broth (MRS, Biokar Diagnostics) at $20^{\circ} \mathrm{C}$ for $24 \mathrm{~h}$. SSOs (Ifremer collection) were grown at $20^{\circ} \mathrm{C}$ in $\mathrm{BHI}$ supplemented with $2 \% \mathrm{NaCl}$ except $P$. phosphoreum, which was cultivated at $15^{\circ} \mathrm{C}$. All strains were stored at $-80^{\circ} \mathrm{C}(50 \%$ culture $+50 \%$ fresh growth medium with $20 \%(\mathrm{v} / \mathrm{v})$ sterile glycerol).

\subsection{Sterile cold-smoked salmon blocks}

Small CSS blocks (approximately $2 \mathrm{~cm}^{3}$ ) were prepared as described by Joffraud et al. (1998), in the best aseptic conditions. They were stored at $-80^{\circ} \mathrm{C}$ and ionized at $4.9 \mathrm{kGy}$ in a plant equipped with cobalt 60 source electron beam facilities (IONISOS, Pouzauges, France). Just after ionization and up 
to 28 days of vacuum storage at $8^{\circ} \mathrm{C}$, the contamination level was less than $1.7 \mathrm{Log} \mathrm{CFU} / \mathrm{g}$ (detection threshold).

\subsection{Spoiling potential of bacteria in sterile cold-smoked salmon blocks}

For each species tested (B. thermosphacta, P. phosphoreum, S. proteamaculans and Carnobacterium divergens), 4 or 5 strains were pre-cultured as described in section 2.2, pooled and diluted in tryptone salt water to reach a concentration of $10^{5} \mathrm{CFU} / \mathrm{mL}$. Eight PCs were pre-cultured and diluted to $10^{8} \mathrm{CFU} / \mathrm{mL}$. The sterile CSS blocks were thawed overnight at $4^{\circ} \mathrm{C}$ and divided into several bags of $120 \mathrm{~g}$ for sensory analysis, $30 \mathrm{~g}$ for microbial analysis and $100 \mathrm{~g}$ for trimethylamine (TMA) and total volatile basic nitrogen (TVBN) analysis. CSS blocks were then inoculated at $2 \%(\mathrm{~V} / \mathrm{m})(1 \%$ culture and $1 \%$ tryptone) with the different groups of bacteria using a micropipette and manually tumbled. The initial concentrations were around $10^{3}-10^{4} \mathrm{CFU} / \mathrm{g}$ for SSOs and $10^{6-7} \mathrm{CFU} / \mathrm{g}$ for PCs. A control was prepared with $2 \%$ tryptone salt water. Bags were then vacuum-packed with a Multivac $A 300 / 16$ machine (Hagenmüller, Wolfertschwenden, Germany) and 90 um-thick PA/PE bags (Sacpo, St Méen le Grand, France). They were stored at $8^{\circ} \mathrm{C}$ for 4 weeks. Microbial, chemical and sensory analyses were carried out at days 14,21 and 28 .

\subsection{Protective effect of bacteria in artificially contaminated cold-smoked salmon blocks}

Based on their spoilage potential, 6 out of 8 PCs were selected to test their protective effect against 4 SSOs. CSS blocks were inoculated using the method described in section 2.4 , at $2 \%(\mathrm{~V} / \mathrm{m})(1 \%$ of each culture). Storage and sampling are described in section 2.4.

\subsection{Protective effect of bacteria in naturally contaminated cold-smoked salmon slices}

Three batches of CSS were bought from a French smokehouse, just after processing, and brought back to the laboratory under chilled conditions. For each batch, a pre-culture of L. piscium EU2241 was aseptically sprayed $(2 \% \mathrm{~V} / \mathrm{m})$ onto each side of 48 slices with an aerographer (Paasches V, 
Paasche Airbrush Company, Illinois, USA) in a laminar flow hood. A control was prepared without added bacteria. CSS slices were then placed on carbon trays (2 slices per tray), vacuum-packed and stored at $4^{\circ} \mathrm{C}$ for 1 week and $8^{\circ} \mathrm{C}$ for 3 weeks, as specified in the French standard for shelf-life validation of perishable and refrigerated food (Afnor NF V 01-003, 2010). Microbial, chemical and sensory analyses were carried out immediately after inoculation and at days 21 and 28 . Pyrosequencing of the 16S rRNA gene was performed at day 21.

\subsection{Sensory analysis of CSS blocks and slices}

Sensory analysis was carried out by 12 trained panelists from Ifremer (selected from 22 candidates after the training session), all experienced in the evaluation of seafood, especially CSS (Joffraud et al., 2006; Varlet et al., 2007). Before starting the experiments, preliminary sessions on odor description were organized. Odors of various CSS batches stored at $8^{\circ} \mathrm{C}$ for different periods, in order to present different levels of spoilage, were described by the panelists and the spoiling level was scored. The training also included sniffing reference odors, alone or in combination, already identified as possibly being produced during seafood spoilage (Joffraud et al., 2001). For all the tests carried out on the CSS blocks (inoculated with SSO, PCs and a combination of SSO and PCS), one bag of $120 \mathrm{~g}$ was opened at each time of analysis and distributed into six polypropylene pots covered with a lid. On the day of the sensory session, all the samples ready for evaluation were kept for one hour at $18^{\circ} \mathrm{C}$ until the session began. Each plastic pot was evaluated by 2 assessors, with a rest time of 30 minutes between the two analyses in order to preserve the sample odor. For tests on naturally contaminated CSS slices, 3 packets with 2 slices of $40 \mathrm{~g}$ were opened on the day of the sensory session and kept open for $10 \mathrm{~min}$ at ambient temperature. Each slice was then cut in half and wrapped in aluminum foil. Within a session, the 3 batches were randomly presented to the assessors; for each batch, the control product was compared to the inoculated product. Panelists were invited to score the level of spoilage on a continuous scale from 0 to 10 and to choose from 1 to 3 main odors from the following descriptors: smoked-fatty fish, grass, butter, acid/vinegar, pyrrolidine, sour/fermented, amine, rancid, cheese, 
sulfur and other. The sensory descriptors were selected during the preliminary sessions. Sessions were performed in individual partitioned booths, equipped with a computerized system (Fizz, Biosystèmes, Couternon, France). Products were assigned 3-digit numbers, presented in a monadic way to the panelists and randomized following the order defined by Williams Latin squares. The effect of bacteria on spoilage scores was estimated by an analysis of variance with assessors and bacteria as independent factors. The significant statistical level was set at $p<0.05$. Data analyses were performed with Fizz software (Biosystèmes, Dijon, France). Frequencies of citation were calculated for odor characteristics and subjected to a correspondence factorial analysis (CFA).

\subsection{Microbial analysis}

Thirty grams of flesh was homogenized with $120 \mathrm{~mL}$ tryptone salt water for $2 \times 2 \mathrm{~min}$. For tests on artificially contaminated CSS blocks with pure cultures, $P$. phosphoreum was enumerated on spread plates of LH incubated at $15^{\circ} \mathrm{C}$ for 5 days, S. proteamaculans on pour plates of TSA/VRBG at $30^{\circ} \mathrm{C}$ for 2 days, $B$. thermosphacta in STAA at $20^{\circ} \mathrm{C}$, L. piscium, L. gelidum, C. divergens, BLN and LYOFLORA FP18 in Elliker at $26^{\circ} \mathrm{C}$, S. equorum in $\mathrm{BHI}$ agar with $2 \%$ of $\mathrm{NaCl}$ at $20^{\circ} \mathrm{C}$ and L. sakei, MCX1113 and BLC48 in MRS at $26^{\circ} \mathrm{C}$. In co-cultures, the same media were used but $C$. divergens was incubated at $33^{\circ} \mathrm{C}$. For tests on naturally contaminated CSS slices, the mother solution was prepared as in section 2.1 (dilution in tryptone salt water + Tween). Total microbiota, total LAB, Enterobacteriaceae and $B$. thermosphacta were enumerated in $\mathrm{LH} 15^{\circ} \mathrm{C}$, Elliker in anaerobic conditions $20^{\circ} \mathrm{C}$ and $30^{\circ} \mathrm{C}$, TSA/VRBG $30^{\circ} \mathrm{C}$ and STAA $20^{\circ} \mathrm{C}$, respectively. Experiments were carried out in triplicate.

\subsection{Pyrosequencing of the $16 \mathrm{~S}$ rRNA gene}

For each sample, the 3 mother solutions of naturally contaminated CSS (see section 2.8) were pooled. Nine milliliters of homogenate was filtered using a NucleoSpin Plant II kit (Macherey Nagel, Hoerdt, France) by centrifugation at 10,000 $\mathrm{g}$. DNA was extracted and purified as described by Macé et al. (2012). The resulting DNA samples were then stored at $-20^{\circ} \mathrm{C}$. Approximately $10 \mathrm{ng}$ DNA was 
used as the PCR template and amplification of the 16S rRNA V1-V3 gene region was performed as described by Chaillou et al. (2014). Three PCR reactions per sample were performed and pooled in equimolar quantities. For each PCR pool, sequencing with the forward primer was carried out using the 454 GS-FLX ++ Titanium platform (Eurofins, Ebersberg, Germany) at an average scale of 80,000 reads per sample. Quality filtering, definition of OTUs, and taxonomic assignment were carried out as in Chaillou et al. (2014) using an updated non-redundant database based on the LTP version 111 (http://www.arb-silva.de/projects/living-tree/).

\subsection{Chemical analysis}

One hundred grams of flesh was homogenized in a Waring Blender (New Hartford, USA). TVBN and TMA were measured in duplicate by the Conway micro-diffusion method (Conway and Byrne, 1933). The $\mathrm{pH}$ value was measured in the five-fold-diluted flesh with a pH-meter (Mettler Delta 320, AES, Combourg, France). Lipid, salt, phenolic compound and water contents were measured by methods described by Cardinal et al. (2004). Briefly, dry matter was analyzed by oven drying at $103^{\circ} \mathrm{C}$. Total fat was determined by hexane extraction and salt was measured with a Chloride Analyzer 926 (Corning, Halstead, England). Total phenols were extracted with ethanol. After different steps including addition of phenyl-2,3-dimethyl-4-amino-5-pyrazolone (Merck, Germany), ammonia, potassium hexacyanoferrate (Prolabo, Fontenay sous bois, France), chloroform and anhydrous sodium sulphate, optical density was read at $455 \mathrm{~nm}$ on a spectrophotometer and compared to a standard curve.

\section{Results and discussion}

\subsection{Selection of target specific spoilage microorganisms}

In a previous study, Chaillou et al. (2014) analyzed 10 batches of commercial CSS coming from 3 smokehouses, with various origins of raw salmon (Ireland, Scotland and Norway) and flesh qualities (normal quality, French "Label Rouge", wild, farmed and organic fish). Samples were stored for 1 
week at $4^{\circ} \mathrm{C}$ followed by 8 weeks at $8^{\circ} \mathrm{C}$. When products were declared spoiled by the sensory panel of Ifremer, the whole microbiota was assessed by amplification and sequencing of the 16S rRNA V1V3 gene region. The most abundant species (both in number of reads and in number of samples contaminated) were B. thermosphacta, P. phosphoreum, C. divergens and S. proteamaculans (Chaillou et al., 2014). In the present study, a collection of several strains of these species was created (Table 1) by isolating bacteria from the spoiled samples in various selective media. Their spoilage potential was then tested by inoculating 4 or 5 strains per species in sterile CSS blocks. The composition of CSS was $60.9 \pm 0.7 \%$ water, $14.9 \pm 0.2 \%$ lipids, $3.9 \pm 0.1 \%$ salt in the water phase and $8.6 \pm 0.5 \mathrm{ppm}$ of phenolic compounds. The inoculation level ranged between 2 and $3 \mathrm{Log}$ (CFU/g) (data not shown). Figure $2 a$ represents the spoilage score determined by the sensory panelists during storage. P. phosphoreum was the highest spoiling bacteria, with a score of 5.6 after 28 days. The odors were described as amine, sour and acid (AFC not shown). Despite the high spoiling capacity of P. phosphoreum, its growth was not very significant, ranging from $3.3 \mathrm{Log}(\mathrm{CFU} / \mathrm{g})$ at day 0 to 5.4 at day 28 (data not shown). Stohr et al. (2001) also showed that $P$. phosphoreum did not grow very well in CSS. They are large rods with a higher production yield of volatile compounds, such as TMA, per cell than other bacteria (Dalgaard, 1995), which could explain this result. B. thermosphacta and S. proteamaculans, which reached 8.5 and $6.4 \mathrm{Log}$ (CFU/g), respectively, in 3 weeks, released off-odors (amine, sour and acid for B. thermosphacta and pyrrolidine and amine for S. proteamaculans), with an overall score of 3.9 and 3.6, respectively, at the end of storage (significantly different from $P$. phosphoreum). These results differ from those of Stohr et al. (2001) who showed that $B$. thermosphacta was the greatest spoiler in sterile CSS, with plastic/butter and rancid odors, while $P$. phosphoreum and Serratia liquefaciens (a species close to S. proteamaculans) produced weaker offodors. However, these three species are known to degrade the sensory quality of many foods. $P$. phosphoreum is responsible for the spoilage of seafood products such as cod (Hovda et al., 2007; Reynisson et al., 2009), salmon (Rudi et al., 2004; Macé et al., 2013) and raw shrimp (Lopez-Caballero et al., 2002) especially under modified atmosphere packaging (MAP). B. thermosphacta has been 
clearly identified by challenge tests as a major spoiler of cooked shrimp stored under MAP (Laursen et al., 2006; Jaffrès et al., 2011) and of MAP salmon fillet (Macé et al., 2013). S. proteamaculans produces strong off-odors in MAP salmon fillet (unpublished data from our laboratory). S. liquefaciens is a great spoiler of cooked shrimp and releases floor cloth off-odors (Jaffrès et al., 2011), but a mix of S. proteamaculans and Serratia spp. did not spoil raw salmon under MAP (Macé et al., 2013). Although C. divergens showed the highest growth (8.8 Log (CFU/g) in 14 days), it was considered a weak spoiler (score of 2.58 , not statistically different from B. thermosphacta and $S$. proteamaculans) characterized by rancid, butter, sour and cheese odors at day 14 and weak amine odors at day 28. C. divergens is able to grow in a wide variety of refrigerated raw and processed meats and seafood products in the presence of preservation additives and smoke components (Laursen et al., 2005). Despite the biochemical and physiological heterogeneity of this species, $C$. divergens has often been shown to be a weak, or even non-, spoiler of seafood (Brillet et al., 2005; Duffes et al., 1999; Jaffrès et al., 2011; Macé et al., 2014).

The absence of a correlation between spoilage and microbial concentration has often been evidenced and led to the SSO concept (Dalgaard, 1995). Accordingly, it is important to confirm the sensory effect of all bacteria present at the time of spoilage to select target SSO strains for the development of a biopreservation strategy (Figure 1).

\subsection{First selection of protective cultures based on bibliographic data}

Eight PCs were selected based on previous studies (Table 1). L. piscium EU2241 and L. gelidum EU2247 improve the sensory quality of shrimp and CSS and inhibit $B$. thermosphacta and $L$. monocytogenes (Brillet-Viel et al., 2011; Fall et al., 2010a, 2010b, 2012; Matamoros et al., 2009b). L. sakei LHIS2885 prevents the formation of histamine, inhibits the growth of various Photobacterium and Morganella species, and delays off-odor formation in tuna (Leroi et al., 2013). Staphylococcus equorum has been isolated in naturally fermented dry sausages and is competitive within its microbial ecosystem (Leroy et al., 2009). As it is present at a relatively high level in CSS (Chaillou et 
al., 2014), its role (spoiler or protective) had to be elucidated. BLN is a commercial starter used to improve the sensory quality of shrimp. LYOFLORA FP-18, BLC48 and MCX1113 are used in meat and seafood to prevent $L$. monocytogenes and spoilage. The selected strains were identified by genomic data and present some safety characteristics such as the absence of biogenic amine production and of transmissible antibiotic resistance (Brillet, 2005; Matamoros et al., 2009a). Additionally, they can easily be produced at high concentration in a fermentor and they resist lyophilization (Brillet, 2005).

\subsection{Second selection of protective cultures based on their implantation and non-spoiling capacity in}

\section{sterile cold-smoked salmon}

PCs were inoculated in sterile CSS blocks. The initial count ranged between 5.2 and 7.4 Log (CFU/g) depending on the strain, and corresponded to industrial practices. All the PCs grew very well, reaching 8.2-9.3 Log (CFU/g), except S. equorum and L. piscium, which reached 6.7 and 7.7 Log (CFU/g), respectively (data not shown). Figure $2 \mathrm{~b}$ presents the spoilage note caused by PCs. L. sakei LHIS2885 released strong sulfurous odors and MCX1113 undesirable acid/fruit odors. They were removed from our selection. Many strains of $L$. sakei are known to produce sulfurous and acidic odors in CSS (Joffraud et al., 2001; Nilsson et al., 1999; Stohr et al., 2001; Truelstrup Hansen et al., 1995) but this feature seems to differ according to the strain. Weiss and Hammes (2006) and Katla et al. (2001) selected non-spoiling L. sakei strains for the biopreservation of this product. Spoilage also depends on the food matrix, as L. sakei LHIS2885 is neutral in tuna stored under vacuum packaging (Podeur, 2014). Although present at a high level, 5 out of 8 PCs had no effect on the sensory quality of CSS and were thus selected for the next step of the screening process. L. piscium has recently been isolated from various products such as vacuum-packed meat (Jiang et al., 2010; Nieminen et al., 2011; Vihavainen et al., 2007), cheese (Carraro et al., 2011), vegetable (Yang et al., 2010) and fish (Macé et al., 2012; Matamoros et al., 2009a; Matsui et al., 2010). The spoiling potential of L. piscium is food- and strain-dependent. Three isolates of $L$. piscium exhibited either a weak spoilage profile or a very offensive metabolism on sweet bell pepper simulation medium, confirming significant intra- 
species diversity (Pothakos et al., 2014). This species has been reported as a spoiler of fresh MAP pork (Rahkila et al., 2012) whereas no off-odor was released by L. piscium in MAP salmon fillets (Macé et al., 2013), MAP peeled and cooked shrimp (Fall et al., 2012) and vacuum-packed CSS (Matamoros et al., 2009b). L. gelidum is a high spoiler in meat products. It causes greening and offodors in raw beef steaks packaged under a high-oxygen modified atmosphere (Vihavainen and Björkroth, 2007), and slimy spoilage and bulging of cooked vegetable sausages packaged under vacuum (Vihavainen et al., 2008). This could be correlated with the presence of genes associated with metabolic pathways involved in buttery off-odor, meat greening, and slime formation (Johansson et al., 2011). L. gelidum has also been shown to form slime and $\mathrm{CO}_{2}$ in acetic acidpreserved herring (Lyhs et al., 2004). On the other hand, different strains of L. gelidum tested in shrimp did not spoil the product (Matamoros et al., 2009b). S. equorum had no negative impact on CSS quality. This species has been recovered at quite a high level in CSS (Chaillou et al., 2014) but its effect has never been tested in CSS before. This study demonstrates that it probably has a minor role in spoilage. A sixth PC, LYOFLORA FP-18, produced butter-like odors but was selected for further tests as this culture is currently used by CSS producers to prevent $L$. monocytogenes risk (communication from Clerici Sacco). For all the strains, the production of TMA was weak, never exceeding $4 \mathrm{mg} / 100 \mathrm{~g}$ of flesh (data not shown), which is explained by the low TMA-oxide content in salmon flesh. TVBN was produced in small quantities of less than $25 \mathrm{mg} / 100 \mathrm{~g}$ by LYOFLORA FP-18, BLC48 and MCX1113. According to Leroi et al. (2001), this concentration is insufficient to be responsible for the sensory deterioration of CSS. The other strains did not produce TVBN.

\subsection{Third selection of protective cultures based on inhibition of specific spoilage microorganisms by} challenge tests in sterile cold-smoked salmon

The anti-microbial effect of the six selected PCs against SSOs was tested by co-inoculation in sterile CSS blocks. The initial levels of contamination for SSOs and PCs were similar to the results previously described (approximately $10^{6} / 10^{2} \mathrm{CFU} / \mathrm{g}$ ). Table 2 summarizes the sensory scores in CSS blocks 
inoculated by SSOs alone or in co-cultures with each PC, after 28 days of storage at $8^{\circ} \mathrm{C}$. The off-odors produced by $P$. phosphoreum were significantly prevented by all PCs except L. piscium EU2241. There was no correlation between the prevention of off-odor and inhibition of $P$. phosphoreum growth. In fact, no, or only very weak, inhibition of $P$. phosphoreum by the PCs was observed (Figure 3a). S. equorum even favored the implantation of $P$. phosphoreum while improving the sensory quality of CSS. This protective effect could not be directly linked to the PC growth as S. equorum survived in CSS but did not grow (Figure 3b). The same statement could be made about the $\mathrm{pH}$ : BLN, BLC48 and $L$. gelidum EU2247 acidified the products to 5.9 (Figure 3c) but their beneficial effect was not significantly greater than LYOFLORA FP-18 (Table 2), which had no effect on pH compared to the control. Spoilage due to B. thermosphacta was reduced by 3 PCs, L. piscium EU2241, LYOFLORA FP-18 and BLC48 (Table 2), and this effect increased after 35 days (data not shown). Surprisingly, while $B$. thermosphacta growth was totally prevented by L. piscium EU2241 (Figure 4a), no inhibitory effect was noticed with BLC48. L. piscium was the strain with the lowest growth (Figure 4b) but the highest positive effect on sensory quality. This improvement in quality was not directly linked to the acidification due to PC metabolism, as L. gelidum EU2247 and BLN, which lowered the $\mathrm{pH}$ to 5.9 (Figure 4c), did not have the highest effect on $B$. thermosphacta growth and sensory quality. The antimicrobial effect of $L$. piscium against $B$. thermosphacta and its positive effect on the sensory quality of cooked shrimp have already been shown by Fall et al. (2010b, 2012).

L. piscium EU2241 was the only strain that limited the spoilage due to S. proteamaculans. BLC48 also had an effect but it was not statistically significant (Table 2). Once again, the sensory improvement was not directly linked to the SSO inhibition. For example, L. piscium had a small effect on the growth of S. proteamaculans (Figure 5) while L. gelidum EU2247 reduced the count of S. proteamaculans by 2 Log units but did not improve the sensory quality. Spoilage due to $C$. divergens was weak, and none of the PCs improved the quality (Table 2), although L. gelidum EU2247 reduced the count of $C$. divergens by 2 Log units (data not shown). 
To conclude, some PCs prevented the sensory deterioration due to SSOs, but the results varied according to the PC/SSO combination tested. L. piscium EU2241 was selected for validation in naturally contaminated CSS because it had the highest protective effect against 2 out of 4 SSOs. BLC48 could also be interesting but was not selected, as its effect was weaker, although its protective effect on $P$. phosphoreum might be useful.

\subsection{Effect of protective cultures in naturally contaminated CSS}

L. piscium was inoculated in 3 batches of commercial CSS at a level of $5.6 \pm 0.0$ Log (CFU/g). After 21 days of storage, the control of batch A was considered highly spoiled by the sensory panel, with a note of $6.0 \pm 1.6$. When the product was inoculated with L. piscium, the quality was improved and the note was $3.6 \pm 1.9$. The abundance of dominant species at 3 weeks, identified by pyrosequencing of $16 \mathrm{~S}$ rRNA genes, is presented in Figure 6a. The dominant bacteria in control A were mainly composed of lactobacilli (L. sakei, L. siliginis, L. curvatus and L. algidus) and L. piscium. These species were never found dominant in the 10 batches analyzed by Chaillou et al. (2014), although batch $A$ originated from 1 of the 3 smokehouses included in that study. To our knowledge, the presence of $L$. piscium has never been reported in CSS before. Many authors have found that Lactobacillus spp. are responsible for CSS spoilage (Nilsson et al., 1999; Stohr et al., 2001, Truelstrup Hansen, 1995) and one can imagine that they caused the strong off-odors of this batch. The sensory quality of bioprotected batch A was significantly improved, but this result is difficult to explain. In fact, $L$. piscium (including L. piscium EU2241) was in a minority in the assay (2.8 Log (read number)) while Lactobacillus spp. were dominant (Figure 6a), as in the control. The classic enumeration method showed that total $\mathrm{LAB}$ growing at $30^{\circ} \mathrm{C}$ (which includes Lactobacillus spp. but not L. piscium unable to grow at this temperature) was higher in the biopreserved batch than in the control ( $7.4 \pm 1.4$ and 5.9 $\pm 1.9 \mathrm{Log}$ (CFU/g), respectively). An inhibitory effect was shown on $B$. thermosphacta $(0.2 \pm 1.1$ and $3.4 \pm 0.5$ (CFU/g) in the assay and control, respectively) but, at this low level, this species cannot be responsible for the spoilage of batch $A$ (Fall, 2011). 
Control batch $\mathrm{C}$ and inoculated batch $\mathrm{C}$ were both considered spoiled after 3 weeks of storage, with sensory scores of $4.4 \pm 2.2$ and $4.0 \pm 2.3$, respectively. No significant difference between the control and assay was noticed for the different counts on LH, Elliker, STAA and VRBG (data not shown). According to the pyrosequencing data, the microbiota of batch $C$ was dominated by $P$. phosphoreum, P. kishitanii, L. sakei and, to a lesser extent, B. thermosphacta $(4.7,4.5,3.7$ and 2.9 Log (read numbers) respectively) and other lactobacilli, which could explain the sensory degradation (Figure 6b). L. piscium added to this batch dominated the microbiota of the assay, with 4.4 Log (read number). As shown in this study (see section 3.4), L. piscium had little effect on P. phosphoreum. This was confirmed by the high level of P. phosphoreum and P. kishitanii in the assay (4.0 and 4.0 Log (read numbers), respectively, Figure 6b) and could explain why L. piscium did not improve the sensory quality of batch C. Surprisingly, although in a minority in the control, L. gasicomitatum and $L$. gelidum became dominant (4.3 and 4.0 Log (read numbers), respectively). Although one strain of $L$. gelidum has been found neutral in CSS (Matamoros et al., 2009b), the involvement of Leuconostoc spp. in the spoilage of bioprotected batch C cannot be excluded (Johansson et al., 2011; Vihavainen et al., 2008).

The results for batch B are not presented because of the huge heterogeneity of slices within the triplicates, both in texture, odor and microbiological content.

To conclude, it is difficult to understand why L. piscium EU2241 had a beneficial effect on the quality of batch $\mathrm{A}$ and not batch $\mathrm{C}$. Biopreservation has been shown to be more efficient when applied to low contaminated products (Brillet-Viel et al., 2011). However, the initial hygienic quality of batch A was very low compared to batch C, with total psychrotrophic counts of $6.4 \pm 1.0$ and $3.6 \pm 0.3 \mathrm{Log}$ (CFU/g), respectively. Moreover, L. piscium EU2241 poorly colonized batch A whereas it was dominant in batch C. Spoiled batch A was dominated by lactobacilli, which were not inhibited by $L$. piscium although the sensory quality was improved in the bioprotected products. Spoilage is very complex, resulting from the metabolism of various bacterial species interacting together. The 
metabiosis and modification of the perception of volatile compounds, when alone or in combination, contribute to this complexity.

All the steps described in this study for the selection of PCs to prevent the sensory degradation of CSS were very long and corresponded to approximately 2 years of work in total. The first step (Figure 1) involving the selection of SSOs was labor-intensive. It included (i) a preliminary study of the microbial ecosystem of CSS using acultural techniques to determine the dominant bacterial species of various batches (Chaillou et al., 2014); (ii) the isolation of different strains belonging to the dominant species and (iii) their capacity to produce off-odors in CSS. The co-inoculation of PCs and SSOs in sterile CSS blocks was also time-consuming. Finally, the diversity of the results between each PC/SSO couple made the selection of one PC difficult. In terms of a strategy to select PCs for improving food quality, and based on the present study, we think that it would be quicker, cheaper and probably lead to more robust results, to test pre select PCs directly in various batches of naturally contaminated CSS. The strategy described in Figure 1 seems more suitable for the selection of PCs to guarantee food safety. In fact, the selection of pathogenic target strains is easy and challenge tests by co-inoculation of PCs and pathogens are necessary, as the contamination level and prevalence in commercial products are often too low to demonstrate the antibacterial efficacy easily.

\section{Acknowledgments}

This study was supported by a public grant from the French Agence Nationale de la Recherche (ANR) within the context of the ALIA (Food Research) program (reference ANR-10-ALIA-018-02, project ECOBIOPRO). We thank VALORIAL and AQUIMER, two French organizations that promote the food industry, for supporting this project, providing advice, and helping to disseminate our results to the French food industry. We also thank Chr Hansen, Clerici Sacco and Biocéane for providing the PCs, and Carol Robins for the English language editing of the manuscript. 


\section{References}

Afnor, 2010. NF V 01-003, 2010. Hygiène des aliments. Lignes directrices pour la réalisation de tests de vieillissement microbiologique - Aliments périssables et très périssables réfrigérés.

Brillet-Viel, A., Pilet, M.F., Chevalier, F., Cardinal, M., Cornet, J., Dousset, X., Joffraud, J.J., Leroi, F., 2011. Biopreservation, a new hurdle technology to improve safety and quality of seafood products. CIGR Section VI International Symposium. Towards a Sustainable Food Chain. Food Process, Bioprocessing and Food Quality Management. Nantes, 18-20 April.

Brillet, A., 2005. Séléction et caractérisation de souches de Carnobacterium pour la preservation du saumon fumé. Ph.D. Thesis, University of Nantes, France.

http://archimer.ifremer.fr/doc/00000/2414/.

Brillet, A., Pilet, M.F., Prévost, H., Bouttefroy, A., Leroi, F., 2004. Biodiversity of Listeria monocytogenes sensitivity to bacteriocin-producing Carnobacterium strains and application in sterile cold-smoked salmon. Journal of Applied Bacteriology 97, 1029-1037.

Brillet, A., Pilet, M.F., Prévost, H., Cardinal, M., Leroi, F., 2005. Effect of inoculation of Carnobacterium divergens V41, a biopreservative strain against Listeria monocytogenes risk, on the microbiological and sensory quality of cold-smoked salmon. International Journal of Food Microbiology 104, 309-324.

Cardinal, M., Gunnlaugsdottir, H., Bjoernevik, M., Ouisse, A., Vallet, J.L., Leroi, F., 2004. Sensory characteristics of cold-smoked Atlantic salmon (Salmo salar) from European market and relationships with chemical, physical and microbiological measurements. Food Research International 37, 181-193.

Carraro, L., Maifreni, M., Bartolomeoli, I., Martino, M.E., Novelli, E., Frigo, F., Marino, M., Cardazzo, B., 2011. Comparison of culture-dependent and -independent methods for bacterial community monitoring during Montasio cheese manufacturing. Research in Microbiology 162, 231-239.

Chaillou, S., Chaulot-Talmon, A., Caekebeke, H., Cardinal, M., Christieans, S., Denis, C., Desmonts, M.H., Dousset, X., Feurer, C., Hamon, E., Joffraud, J.-J., La Carbona, S., Leroi, F., Leroy, S., Lorre, S., 
Macé, S., Pilet, M.-F., Prévost, H., Rivollier, M., Roux, D., Talon, R., Zagorec, M., ChampomierVergès, M.-C., 2014. Origin and ecological selection of core and food-specific bacterial communities associated with meat and seafood spoilage. The Isme Journal, 1-14.

Conway, E.J., Byrne, A., 1933. An absorption apparatus for the micro-determination of certain volatile substances. I. The micro-determination of ammonia. Biochemical Journal 27, 419-429. Dalgaard, P., 1995. Qualitative and quantitative characterization of spoilage bacteria from packed fish. International Journal of Food Microbiology 26, 319-333.

Doré, B., 2008. Introduction to part III: Ensuring seafood safety, in: Borresen, T. (Ed.), Improving seafood products for the consumer. Woodhead Publishing Limited, Cambridge, pp. 185-193.

Duffes, F., Corre, C., Leroi, F., Dousset, X., Boyaval, P., 1999. Inhibition of Listeria monocytogenes by in situ produced and semipurified bacteriocins of Carnobacterium spp. on vacuum-packed, refrigerated cold-smoked salmon. Journal of Food Protection 62, 1394-1403.

Fall, P.A., 2011. Études des interactions entre la bactérie bioprotectrice Lactococcus piscium et Brochothrix thermosphacta et Listeria monocytogenes dans la crevette tropicale. Ph.D. Thesis, University of Nantes, France. http://archimer.ifremer.fr/doc/00050/16164/.

Fall, P.A., Leroi, F., Chevalier, F., Guerin, C., Pilet, M.F., 2010a. Protective effect of a nonbacteriocinogenic Lactococcus piscium CNCM I-4031 strain against Listeria monocytogenes in sterilized tropical cooked peeled shrimp. Journal of Aquatic Food Product Technology 19, 84 - 92.

Fall, P.A., Leroi, F., Cardinal, M., Chevalier, F., Pilet, M.F., 2010b. Inhibition of Brochothrix thermosphacta and sensory improvement of tropical peeled cooked shrimp by Lactococcus piscium CNCM I-4031. Letters in Applied Microbiology 50, 357-361.

Fall, P.A., Pilet, M.F., Leduc, F., Cardinal, M., Duflos, G., Guérin, C., Joffraud, J.J., Leroi, F., 2012. Sensory and physicochemical evolution of tropical cooked peeled shrimp inoculated by Brochothrix thermosphacta and Lactococcus piscium CNCM I-4031 during storage at $8^{\circ} \mathrm{C}$. International Journal of Food Microbiology 152, 82-90. 
FAO, 2011. Global food losses and food waste. Extent, causes and prevention. Study conducted for the International Congress. Food and Agriculture Organization.

http://www.fao.org/docrep/014/mb060e/mb060e00.htm.

Ghanbari, M., Jami, M., Domig, K.J., Kneifel, W., 2013. Seafood biopreservation by lactic acid bacteria: A review. LWT - Food Science and Technology 54, 315-324.

Hovda, M.B., Lunestad, B.T., Sivertsvik, M., Rosnes, J.T., 2007. Characterisation of the bacterial flora of modified atmosphere packaged farmed Atlantic cod (Gadus morhua) by PCR-DGGE of conserved 16S rRNA gene regions. International Journal of Food Microbiology 117, 68-75.

Jaffrès, E., Lalanne, V., Macé, S., Cornet, J., Cardinal, M., Sérot, T., Dousset, X., Joffraud, J.J., 2011. Sensory characteristics of spoilage and volatile compounds associated with bacteria isolated from cooked and peeled tropical shrimps using SPME-GC-MS analysis. International Journal of Food Microbiology 147, 195-202.

Jami, M., Ghanbari, M., Zunabovic, M., Domig, K.J., Kneifel, W., 2014. Listeria monocytogenes in Aquatic Food Products - A Review. Comprehensive Reviews in Food Science and Food Safety 13, 798-813.

Jiang, Y., Gao, F., Xu, X.L., Su, Y., Ye, K.P., Zhou, G.H., 2010. Changes in the bacterial communities of vacuum-packaged pork during chilled storage analyzed by PCR-DGGE. Meat Science 86, 889-895. Joffraud, J.J., Cardinal, M., Cornet, J., Chasles, J.S., Léon, S., Gigout, F., Leroi, F., 2006. Effect of bacterial interactions on the spoilage of cold-smoked salmon. International Journal of Food Microbiology 112, 51-61.

Joffraud, J.J., Leroi, F., Chevalier, F., 1998. Development of a sterile cold-smoked fish model. Journal of Applied Microbiology 85, 991-998.

Joffraud, J.J., Leroi, F., Roy, C., Berdagué, J.L., 2001. Characterisation of volatile compounds produced by bacteria isolated from the spoilage flora of cold-smoked salmon. International Journal of Food Microbiology 66, 175-184. 
Johansson, P., Paulin, L., Sade, E., Salovuori, N., Alatalo, E.R., Bjorkroth, K.J., Auvinen, P., 2011.

Genome sequence of a food spoilage lactic acid bacterium, Leuconostoc gasicomitatum LMG $18811 \mathrm{~T}$, in association with specific spoilage reactions. Applied and Environmental Microbiology $77,4344-4351$.

Katla, T., Moretro, T., Aasen, I.M., Holck, A., Axelsson, L., Naterstad, K., 2001. Inhibition of Listeria monocytogenes in cold smoked salmon by addition of sakacin P and/or live Lactobacillus sakei cultures. Food Microbiology 18, 431-439.

Laursen, B.G., Bay, L., Cleenwerck, I., Vancanneyt, M., Swings, J., Dalgaard, P., Leisner, J.J., 2005. Carnobacterium divergens and Carnobacterium maltaromicum as spoilers or protective cultures in meat and seafood: phenotypic and genotypic characterisation. Systematic Applied Microbiology $28,151-164$.

Laursen, B.G., Leisner, J.J., Dalgaard, P., 2006. Carnobacterium species: Effect of metabolic activity and interaction with Brochothrix thermosphacta on sensory characteristics of modified atmosphere packed shrimp. Journal of Agricultural and Food Chemistry 54, 3604-3611.

Leroi, F., 2010. Occurrence and role of lactic acid bacteria in seafood products. Food Microbiology 27, 698-709.

Leroi, F., Arbey, N., Joffraud, J.J., Chevalier, F., 1996. Effect of inoculation with lactic acid bacteria on extending the shelf life of vacuum-packed cold smoked salmon lactic acid starters and cold smoked salmon. International Journal of Food Science \& Technology, 31, 6, 497-504.

Leroi, F., Joffraud, J.J., Chevalier, F., Cardinal, M., 2001. Research of quality indices for cold-smoked salmon using a stepwise multiple regression of microbiological counts and physico-chemical parameters. Journal of Applied Microbiology 90, 578-587.

Leroi, F., Podeur, G., Prévost, H., Pilet, M.F., 2013. Patent INPI n¹353586. Utilisation de Lactobacillus sakei pour la biopréservation des produits de la mer. 
Leroy, S., Lebert, I., Chacornac, J.-P., Chavant, P., Bernardi, T., Talon, R., 2009. Genetic diversity and biofilm formation of Staphylococcus equorum isolated from naturally fermented sausages and their manufacturing environment. International Journal of Food Microbiology 134, 46-51.

López-Caballero, M., Gonçalves, A., Nunes, M., 2002. Effect of $\mathrm{CO}_{2} / \mathrm{O}_{2}$-containing modified atmospheres on packed deepwater pink shrimp (Parapenaeus longirostris). European Food Research and Technology 214, 192-197.

Lyhs, U., Koort, J.M.K., Lundstrom, H.S., Bjorkroth, K.J., 2004. Leuconostoc gelidum and Leuconostoc gasicomitatum strains dominated the lactic acid bacterium population associated with strong slime formation in an acetic-acid herring preserve. International Journal of Food Microbiology 90, 207-218.

Macé, S., Cardinal, M., Jaffres, E., Cornet, J., Lalanne, V., Chevalier, F., Sérot, T., Pilet, M.F., Dousset, X., Joffraud, J.J., 2014. Evaluation of the spoilage potential of bacteria isolated from spoiled cooked whole tropical shrimp (Penaeus vannamei) stored under modified atmosphere packaging. Food Microbiology 40, 9-17.

Macé, S., Cornet, J., Chevalier, F., Cardinal, M., Pilet, M.F., Dousset, X., Joffraud, J.J., 2012 Characterisation of the spoilage microbiota in raw salmon (Salmo salar) steaks stored under vacuum or modified atmosphere packaging combining conventional methods and PCR-TTGE. Food Microbiology 30, 164-172.

Macé, S., Joffraud, J.J., Cardinal, M., Malcheva, M., Cornet, J., Lalanne, V., Chevalier, F., Sérot, T., Pilet, M.F., Dousset, X., 2013. Evaluation of the spoilage potential of bacteria isolated from spoiled raw salmon (Salmo salar) fillets stored under modified atmosphere packaging. International Journal of Food Microbiology 160, 227-238.

Matamoros, S., Pilet, M.F., Gigout, F., Prévost, H., Leroi, F., 2009a. Selection and evaluation of seafood-borne psychrotrophic lactic acid bacteria as inhibitors of pathogenic and spoilage bacteria. Food Microbiology 26, 638-644. 
Matamoros, S., Leroi, F., Cardinal, M., Gigout, F., Kasbi Chadli, F., Cornet, J., Prevost, F., Pilet, M.F., 2009b. Psychrotrophic lactic acid bacteria used to improve the safety and quality of vacuumpackaged cooked and peeled tropical shrimp and cold-smoked salmon. Journal of Food Protection $72,365-374$.

Matsui, H., Saka, E., Isobe, Y., Narita, M., 2010. Comparison of the bacterial community structures of Ayu-narezushi produced by two different manufacturers. Biocontrol Science 15, 63-68.

Nieminen, T.T., Vihavainen, E., Paloranta, A., Lehto, J., Paulin, L., Auvinen, P., Solismaa, M., Bjorkroth, K.J., 2011. Characterization of psychrotrophic bacterial communities in modified atmospherepacked meat with terminal restriction fragment length polymorphism. International Journal of Food Microbiology 144, 360-366.

Nilsson, L., Gram, L., Huss, H.H., 1999. Growth control of Listeria monocytogenes on cold-smoked salmon using a competitive lactic acid bacteria flora. Journal of Food Protection 62, 336-342.

Odeyemi, A.O., Ahmad, A., Usup, G., In-vitro antimicrobial activity of Aeromonas spp isolated from estuary using different screening protocols. International Journal of Pharmaceutical Science and Research 3 (2), 428-433.

Pilet, M.F., Leroi, F., 2011. Applications of protective cultures, bacteriocins and bacteriophages in fresh seafood and seafood products, in: Lacroix, C. (Ed.), Protective cultures, antimicrobial metabolites and bacteriophages for food and beverage biopreservation. Woodhead Publishing Limited, Oxford, Cambridge, Philadelphia, New Delhi, pp. 324-347.

Podeur, G., 2014. Quantification des bactéries histaminogènes et maîtrise de la formation d'histamine dans les produits marins par biopréservation. Ph.D. thesis, University of Nantes. http://archimer.ifremer.fr/doc/00241/35203/33709.pdf

Pothakos, V., Nyambi, C., Zhang, B.Y., Papastergiadis, A., De Meulenaer, B., Devlieghere, F., 2014. Spoilage potential of psychrotrophic lactic acid bacteria (LAB) species: Leuconostoc gelidum subsp. gasicomitatum and Lactococcus piscium, on sweet bell pepper (SBP) simulation medium under different gas compositions. International Journal of Food Microbiology 178, 120-129. 
Rahkila, R., Nieminen, T.T., Johansson, P., Sade, E., Borkroth, J., 2012. Characterization and evaluation of the spoilage potential of Lactococcus piscium isolates from modified atmosphere packaged meat. International Journal of Food Microbiology 156, 50-59.

Reynisson, E., Lauzon, H., Magnusson, H., Jonsdottir, R., Olafsdottir, G., Marteinsson, V., Hreggvidsson, G.O., 2009. Bacterial composition and succession during storage of North-Atlantic cod (Gadus morhua) at superchilled temperatures. BMC Microbiology 9, 250.

Rudi, K., Maugesten, T., Hannevik, S.E., Nissen, H., 2004. Explorative multivariate analyses of $16 \mathrm{~S}$ rRNA gene data from microbial communities in modified-atmosphere-packed salmon and coalfish. Applied and Environmental Microbiology 70, 5010-5018.

Stohr, V., Joffraud, J.J., Cardinal, M., Leroi, F., 2001. Spoilage potential and sensory profile associated with bacteria isolated from cold-smoked salmon. Food Research International 34, 797-806.

Tahiri, I., Desbiens, M., Kheadr, E., Lacroix, C., Fliss, I., 2009. Comparison of different application strategies of divergicin M35 for inactivation of Listeria monocytogenes in cold-smoked wild salmon. Food Microbiology 26, 783-793.

Truelstrup Hansen, L., Gill, T., Huss, H.H., 1995. Effects of salt and storage temperature on chemical, microbiological and sensory changes in cold-smoked salmon. Food Research International 28, 123-130.

Van Spreekens, K.J.A., 1974. The suitability of a modification of Long and Hammer's medium for the enumeration of more fastidious bacteria from fresh fisheries products. Archiv für Lebensmittelhygiene 25, 213-219.

Varlet, V., Serot, T., Knockaert, C., Cornet, J., Cardinal, M., Monteau, F., Le Bizec, B., Prost, C., 2007. Organoleptic characterization and PAH content of salmon (Salmo salar) fillets smoked according to four industrial smoking techniques. Journal of the Science of Food and Agriculture 87, 847-854. Vihavainen, E., Lundström, H.-S., Susiluoto, T., Koort, J., Paulin, L., Auvinen, P., Björkroth, K.J., 2007. Role of broiler carcasses and processing plant air in contamination of modified-atmosphere- 
packaged broiler products with psychrotrophic lactic acid bacteria. Applied and Environment Microbiology 73, 1136-1145.

Vihavainen, E.J., Bjorkroth, K.J., 2007. Spoilage of value-added, high-oxygen modified-atmosphere packaged raw beef steaks by Leuconostoc gasicomitatum and Leuconostoc gelidum. International Journal of Food Microbiology 119, 340-345.

Vihavainen, E.J., Murros, A.E., Bjorkroth, K.J., 2008. Leuconostoc spoilage of vacuum-packaged vegetable sausages. Journal of Food Protection 71, 2312-2315.

Weiss, A., Hammes, W.P., 2006. Lactic acid bacteria as protective cultures against Listeria spp. on cold-smoked salmon. European Food Research and Technology 222, 343-346.

Yang, J., Cao, Y., Cai, Y., Terada, F., 2010. Natural populations of lactic acid bacteria isolated from vegetable residues and silage fermentation. Journal of Dairy Science 93, 3136-3145.

Zagorec, M., Christieans, S., 2013. Avant-propos, in: Zagorec, M., Christieans, S. (Eds.), Flores protectrices pour la conservation des aliments. Quae, Versailles (France), p. VII. 
Figure 1: Strategy for the selection of protective cultures to improve food quality and safety

Figure 2: Sensory score of (a) specific spoilage organisms and (b) presumptive protective cultures assessed by sensory evaluation in artificially inoculated cold-smoked salmon blocks stored under vacuum packaging for 28 days at $8^{\circ} \mathrm{C}$

Figure 3: Growth of (a) P. phosphoreum alone and in co-culture with protective cultures, (b) protective cultures in the presence of $P$. phosphoreum and (c) pH in cold-smoked salmon blocks artificially inoculated and stored under vacuum packaging for 28 days at $8^{\circ} \mathrm{C}$

Figure 4: Growth of (a) B. thermosphacta alone and in co-culture with protective cultures, (b) protective cultures in the presence of $B$. thermosphacta and (c) pH in cold-smoked salmon blocks artificially inoculated and stored under vacuum packaging for 28 days at $8^{\circ} \mathrm{C}$

Figure 5: Growth of S. proteamaculans alone and in co-culture with protective cultures in coldsmoked salmon blocks artificially inoculated and stored under vacuum packaging for 28 days at $8^{\circ} \mathrm{C}$ Figure 6: Abundance of dominant species in (a) batch A (control or bioprotected with L. piscium EU2241) and (b) batch C (control or bioprotected with L. piscium EU2241), after 3 weeks of storage (1 week at $4^{\circ} \mathrm{C}$ and 2 weeks at $8^{\circ} \mathrm{C}$ ) 
Table 1: List of specific spoilage organisms and bioprotective cultures

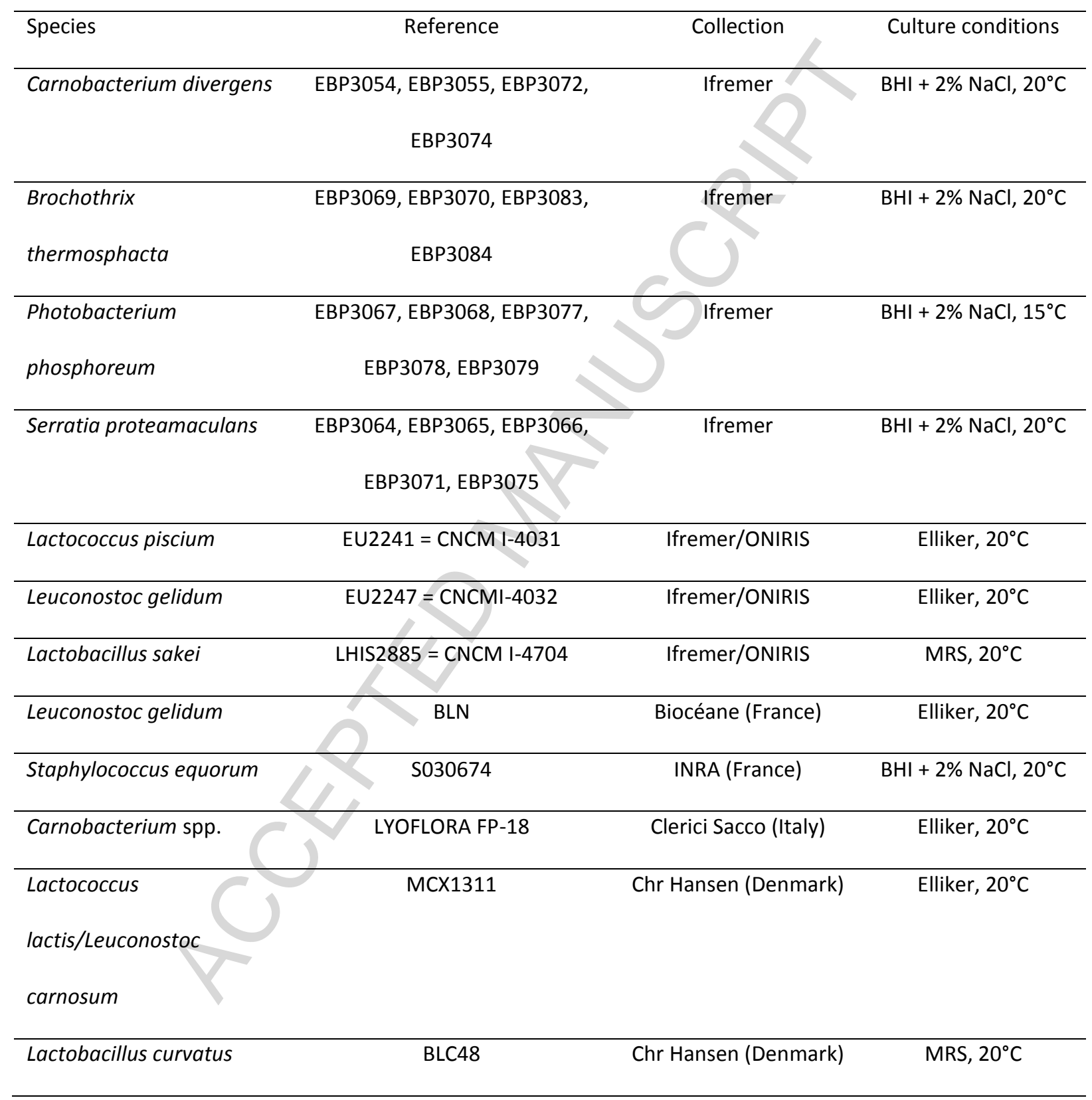


Table 2: Sensory note (mean of 12 panelists) of cold-smoked salmon blocks inoculated with SSO alone or SSO plus PC after 4 weeks of storage at $8^{\circ} \mathrm{C}$, on a scale ranging from 0 to 10 ( 0 corresponding to unspoiled product and 10 to strongly spoiled product).

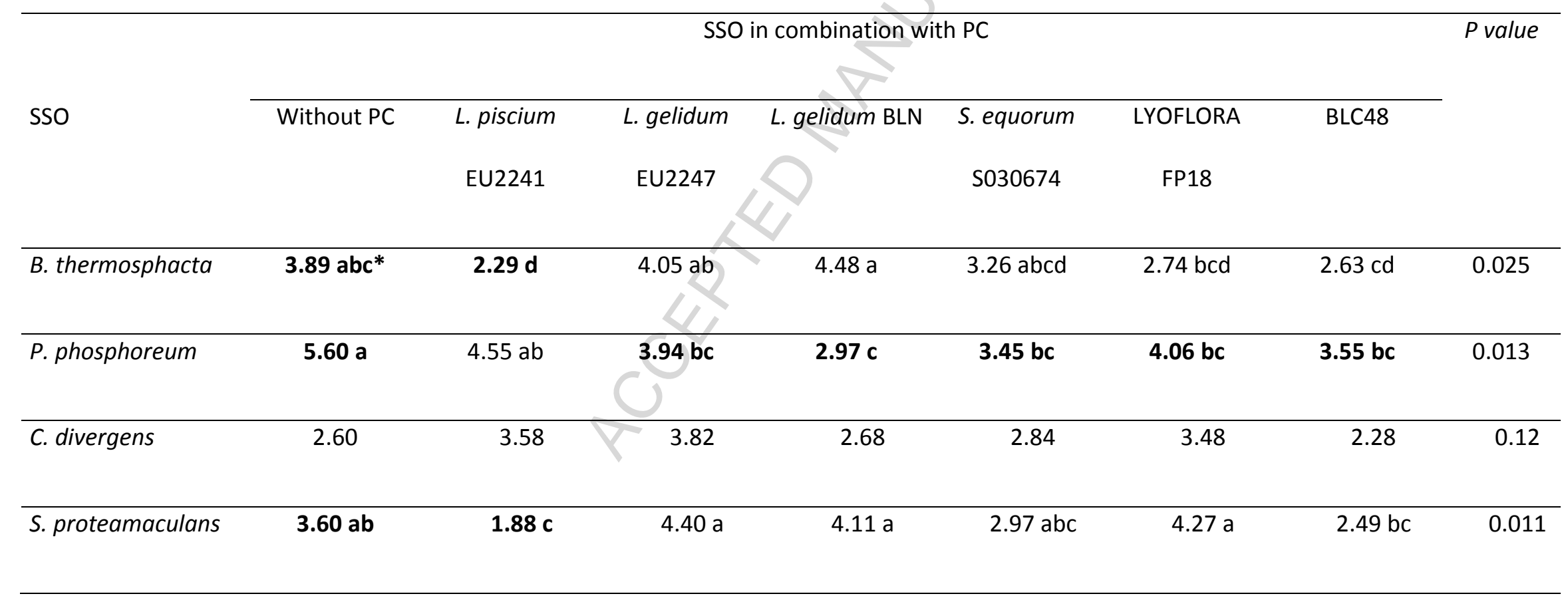

* Means with different letters a, b, c are significantly different with Duncan's multiple range test $(P<0.10)$ 
Selection of target strain to inhibit pathogenic or spoiling microorganisms

\section{Collection of presumptive protective culture (PC)} commercial culture, private collection...

\section{$1^{\text {st }}$ selection of PC}

inhibition of target bacteria in model conditions

$2^{\text {nd }}$ selection

taxonomy, physiology of PC (growth at low temperature, acid production...)

$$
3^{\text {rd }} \text { selection }
$$

safety (antibiogram, toxicity...), technology (resistance to lyophilization, production of strain...) $4^{\text {th }}$ selection

absence of spoiling capacity in sterile food

$5^{\text {th }}$ selection

inhibition of target bacteria in sterile food (challenge tests)

\section{$6^{\text {th }}$ selection}

validation in naturally contaminated products

Fig. 1 
Figure $2 \mathrm{~A}$

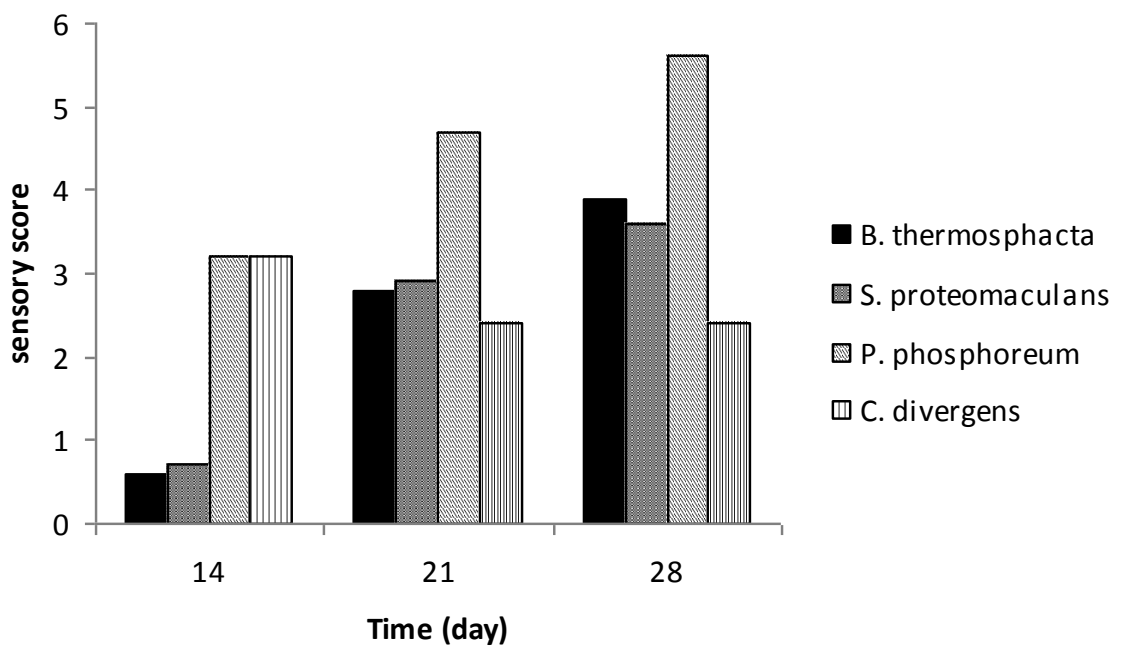

Figure $2 \mathrm{~B}$

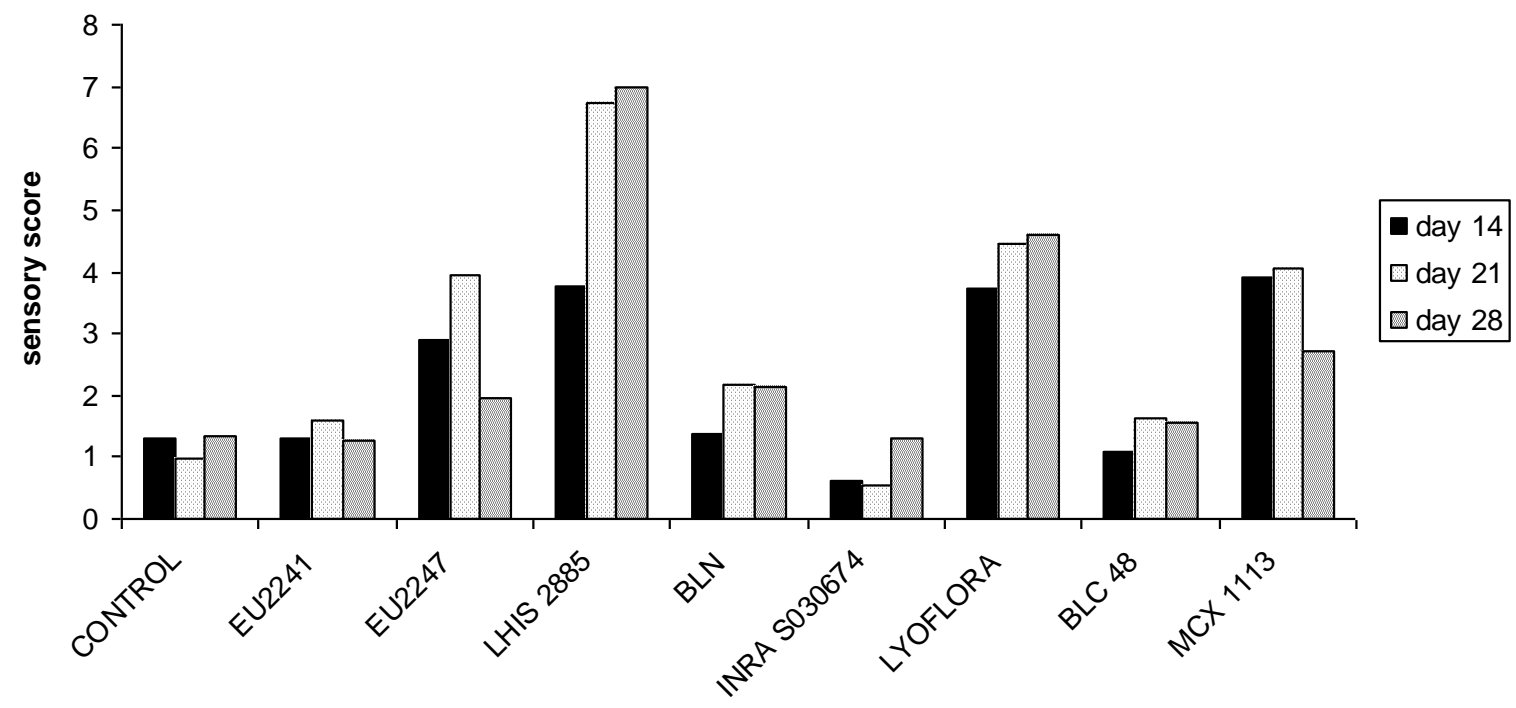

Fig. 2 

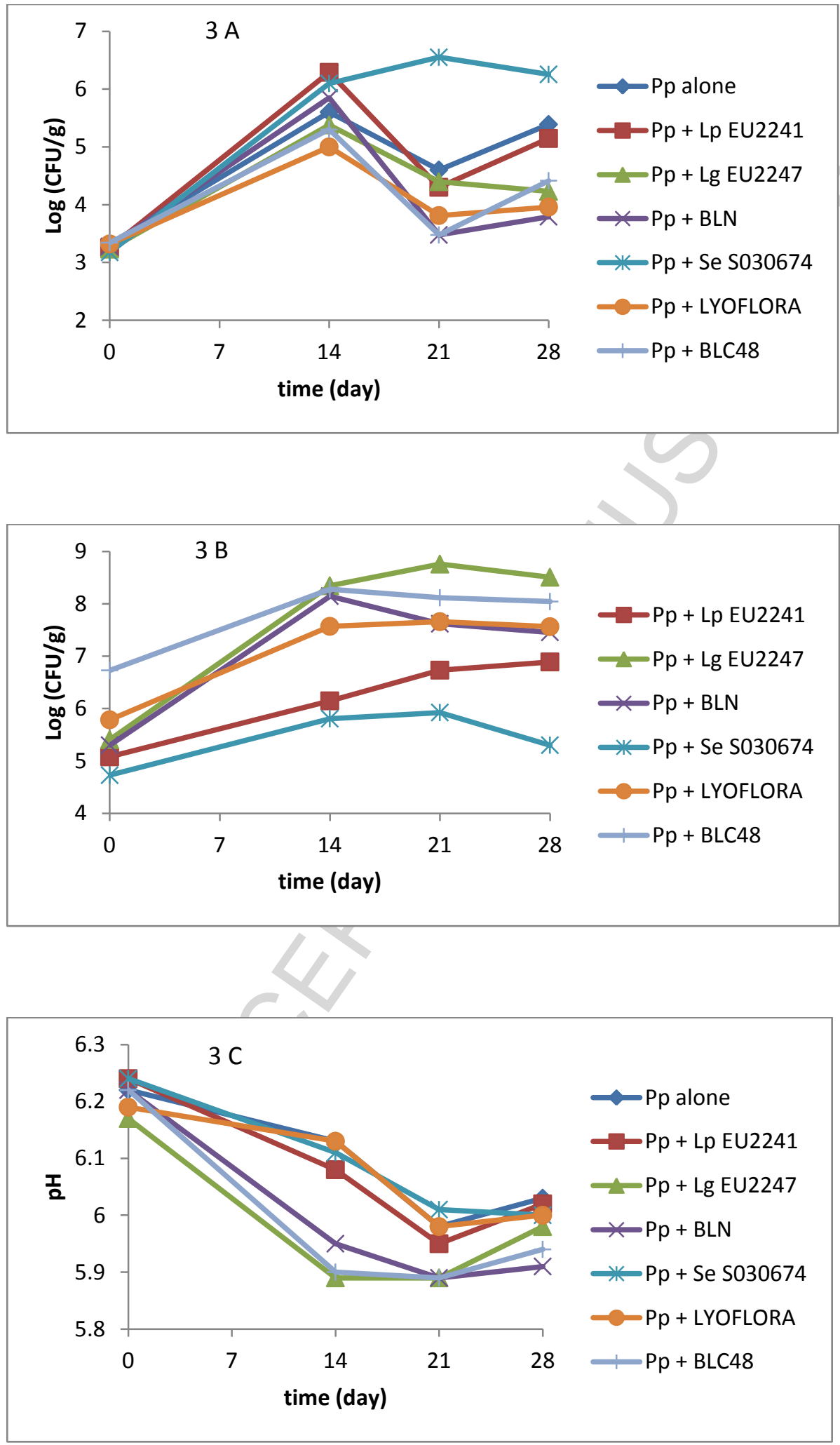

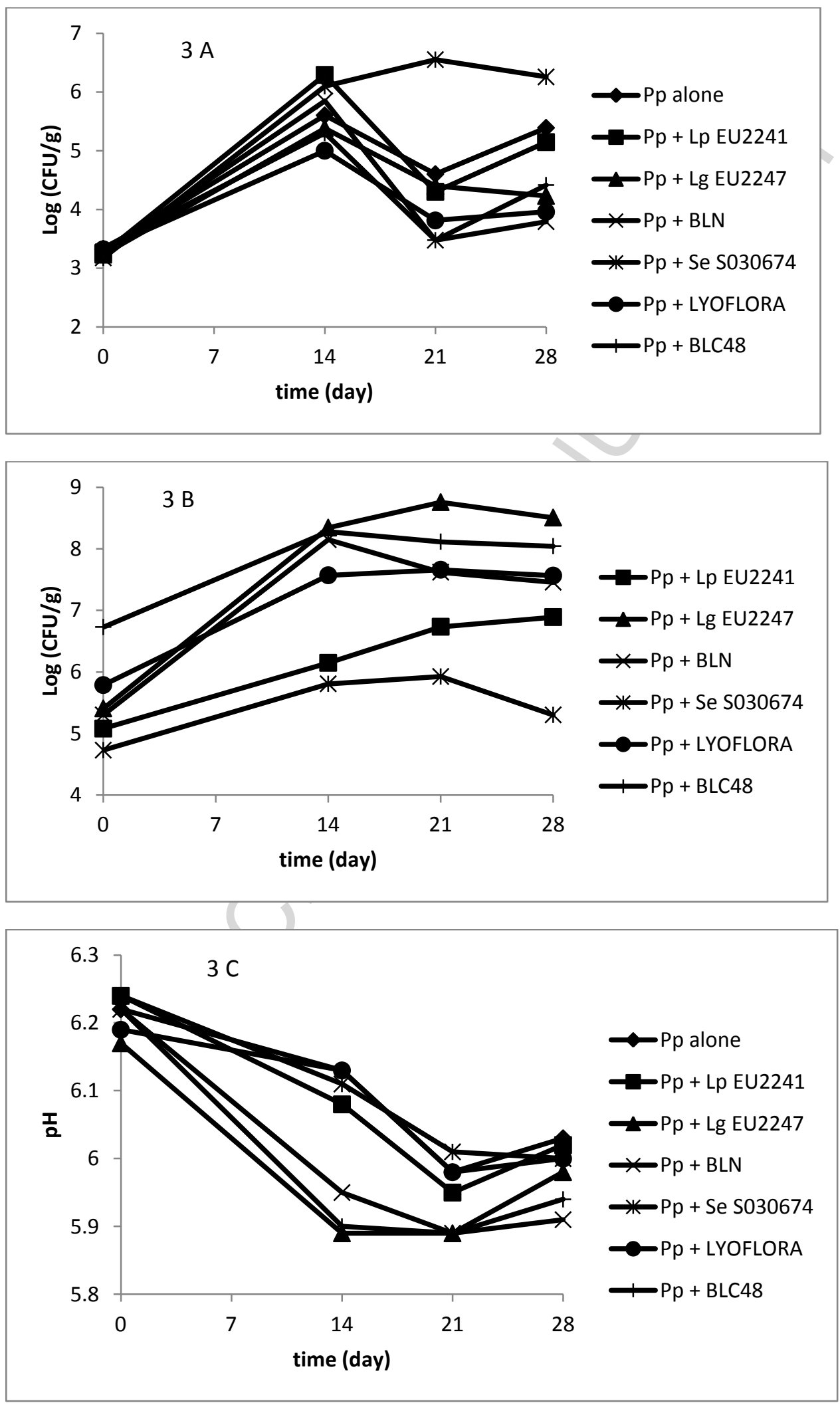

Fig. 3 

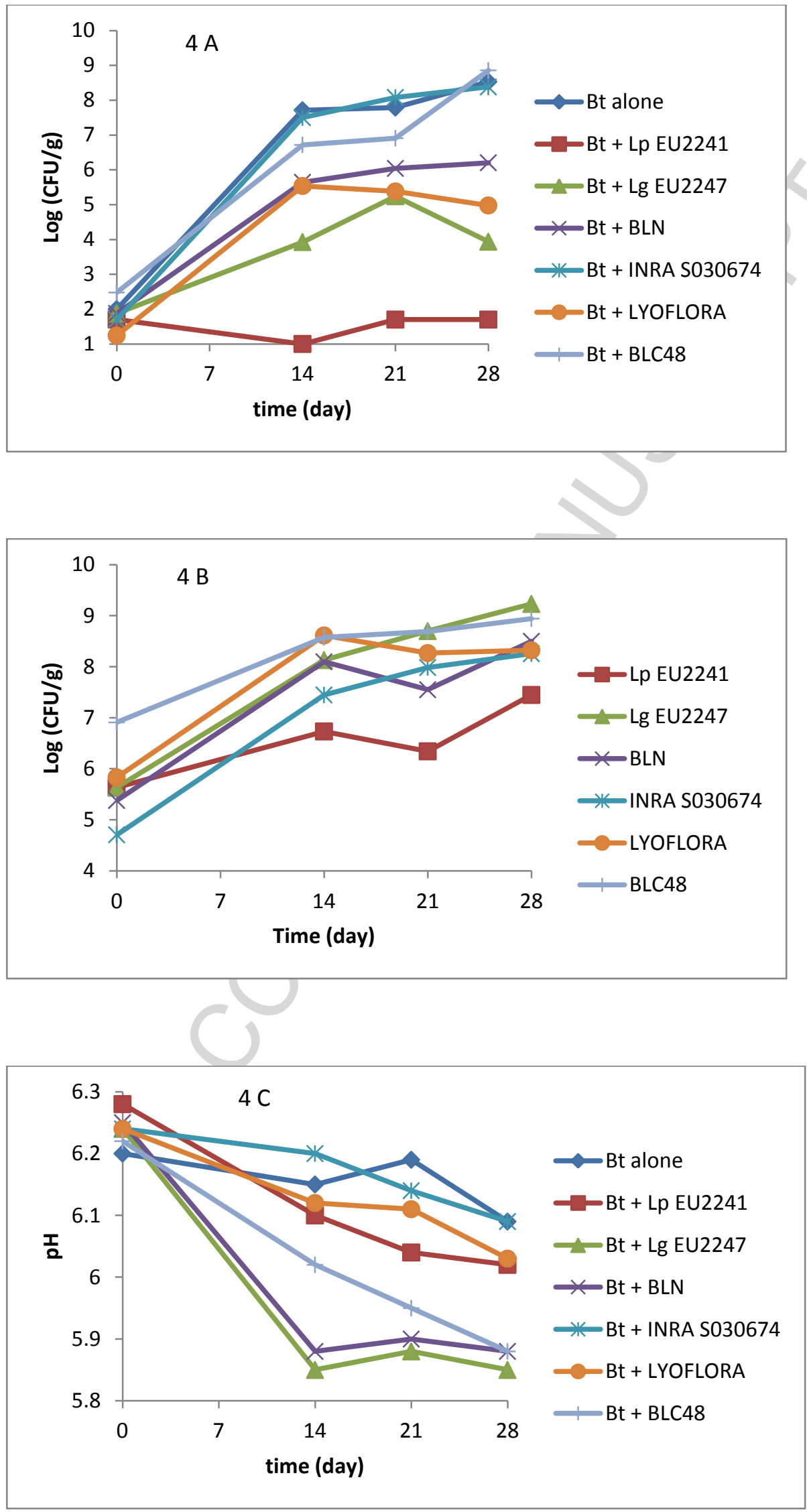

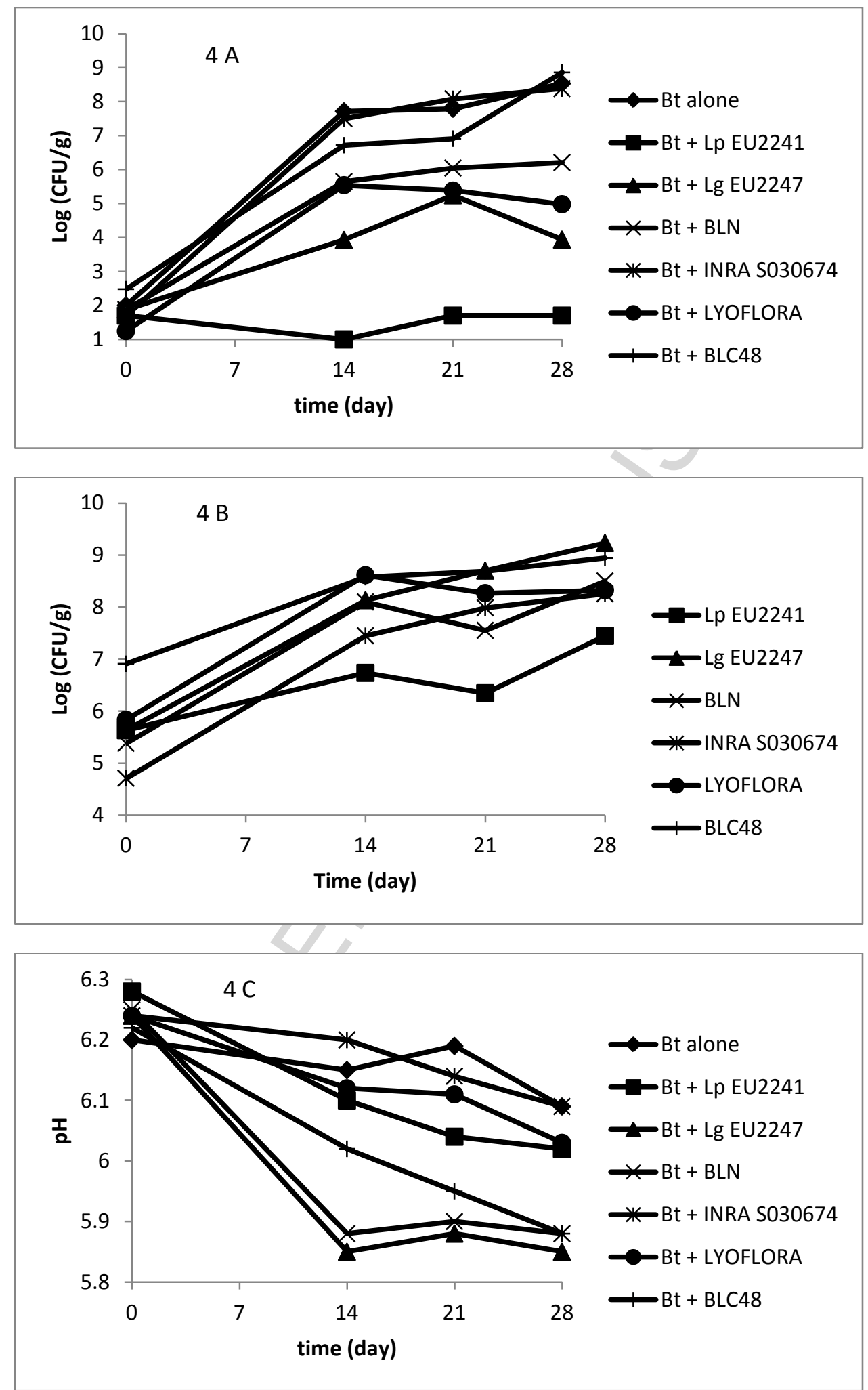

Fig. 4 

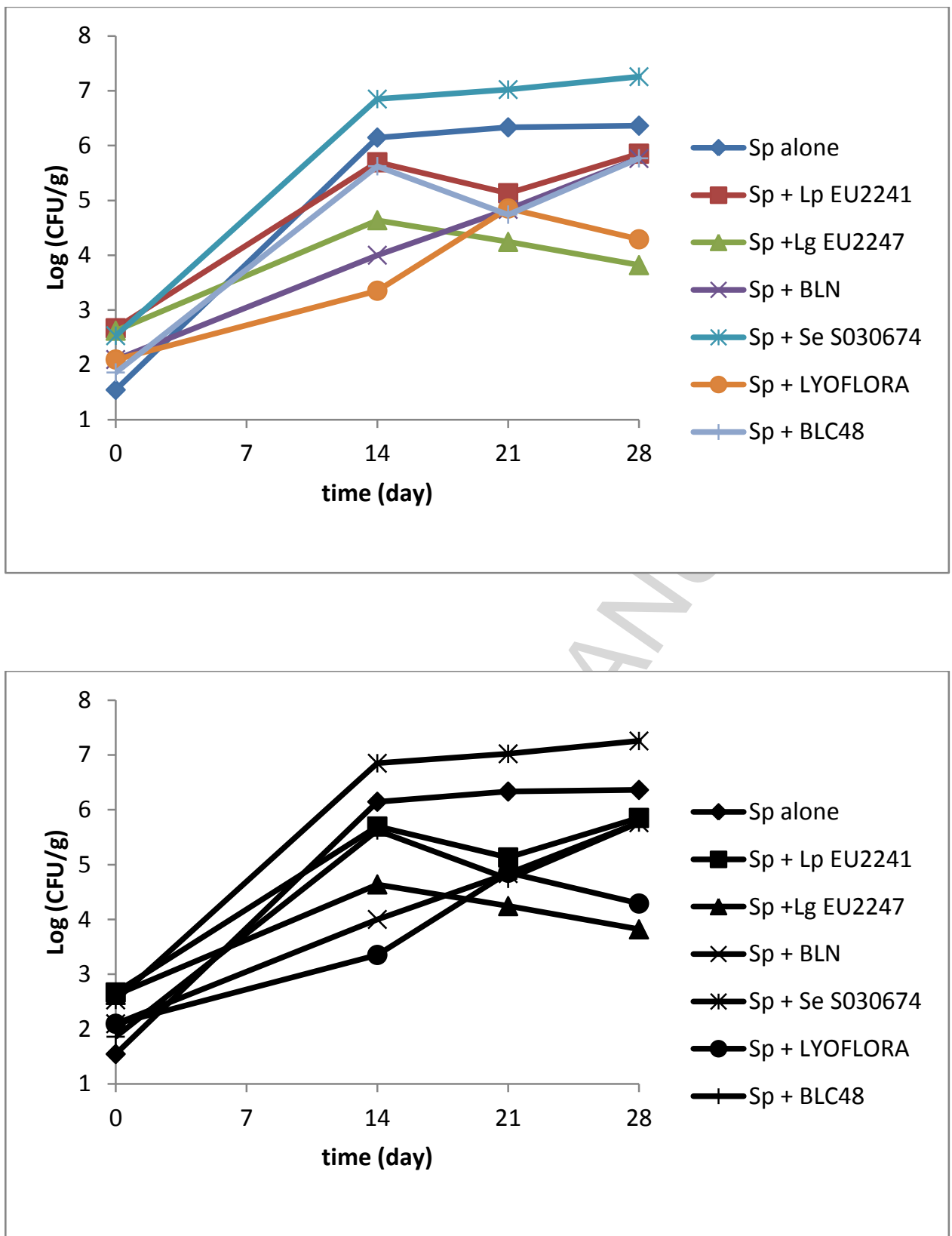

Fig. 5 
Fig 6 A (Batch A)

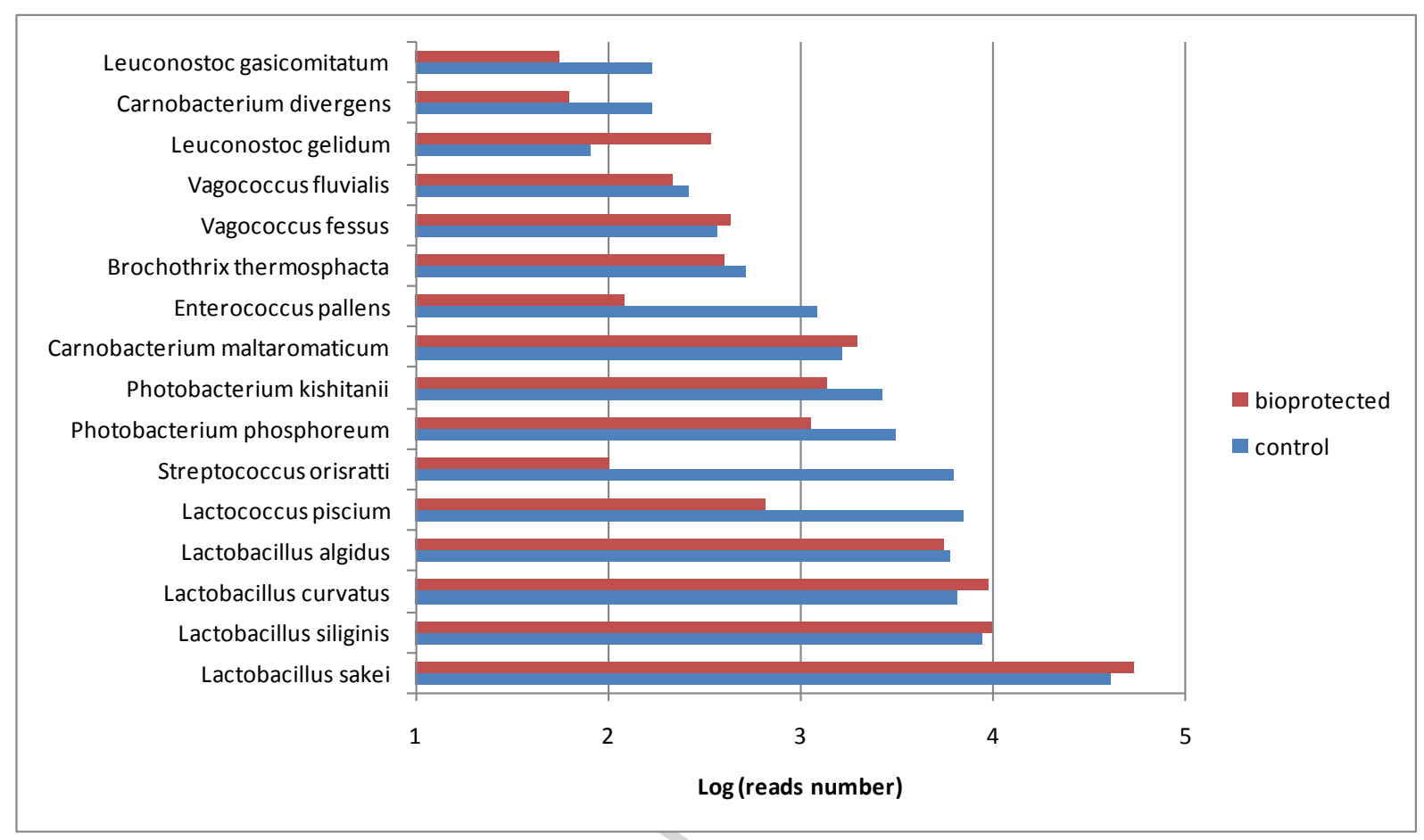

Fig 6 B (Batch C)

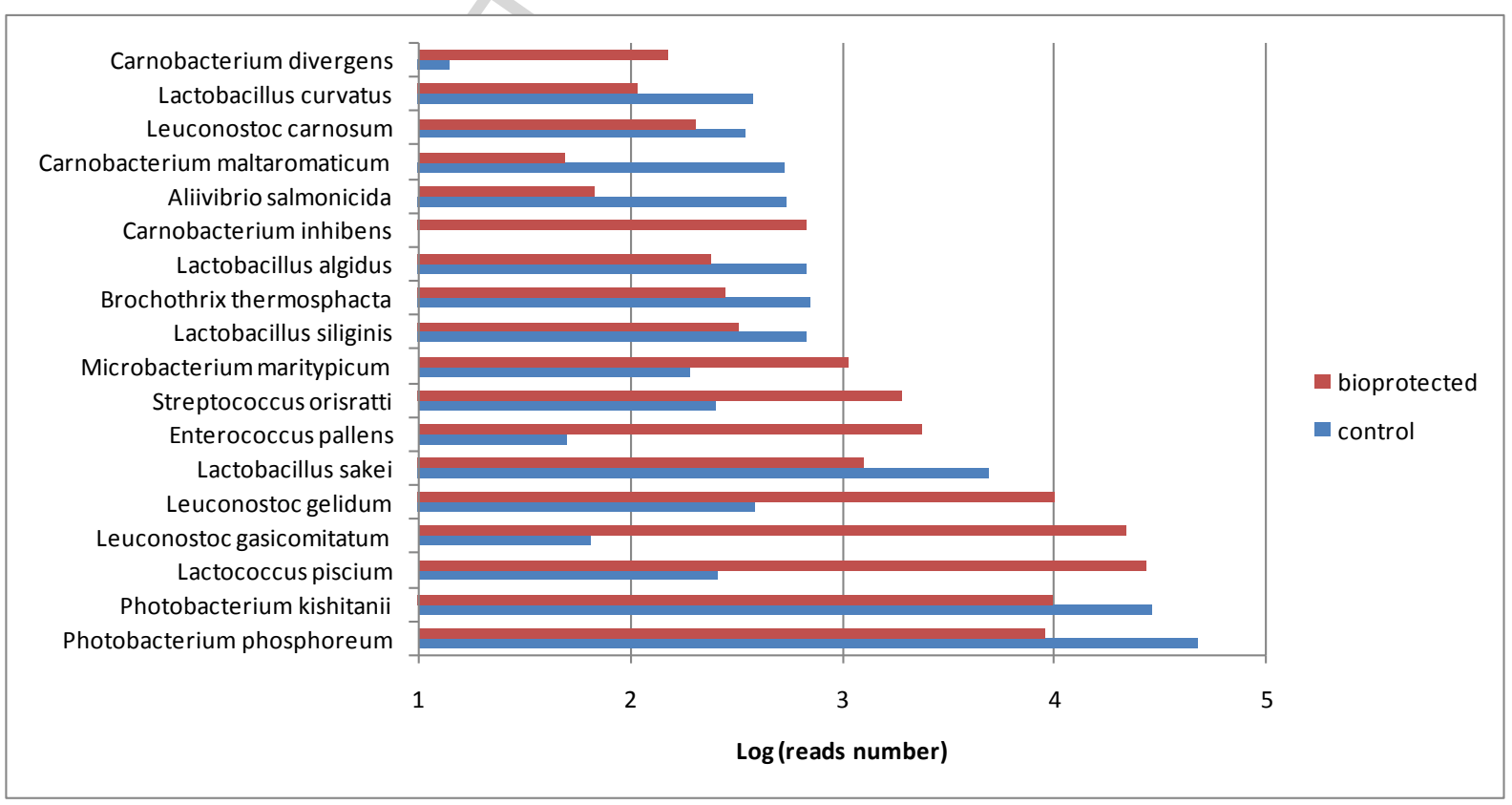


Fig 6 A (Batch A)

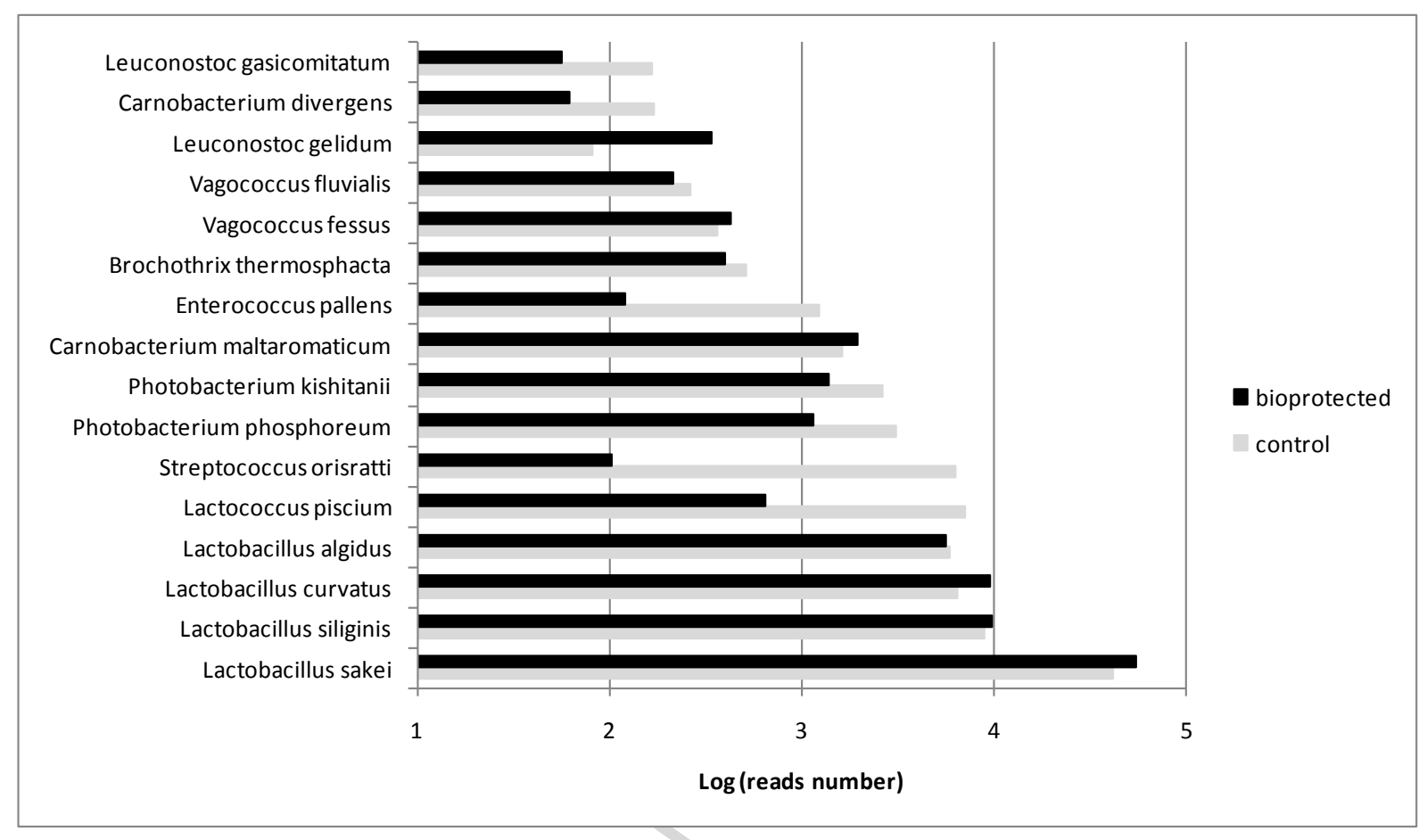

Fig 6 B (Batch C)

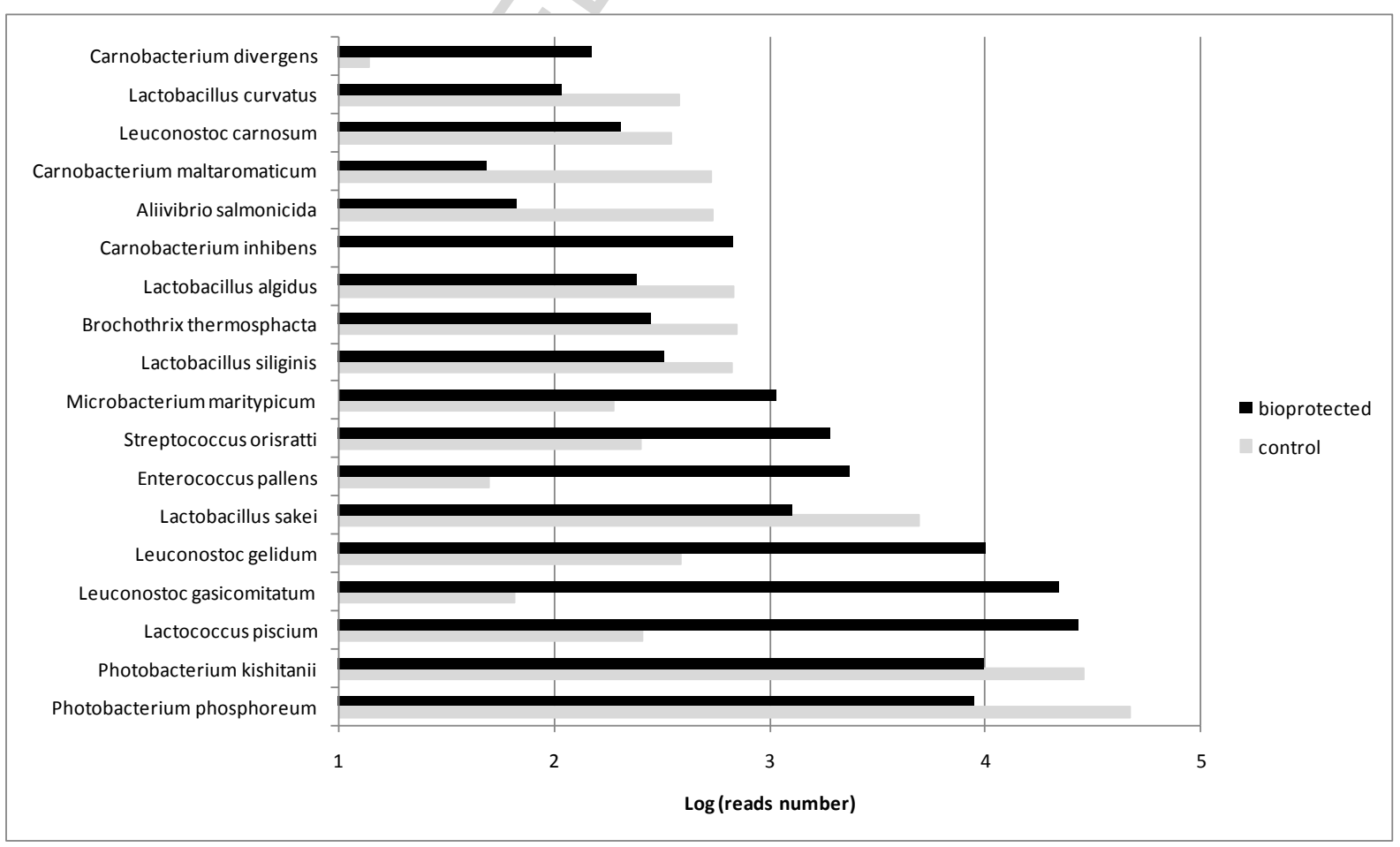

Fig. 6 